\title{
PRODUCTIVITY AND TRADE DURING THE SOFTWOOD LUMBER DISPUTE
}

\author{
Rao V. Nagubadi \\ Henry Thompson \\ Daowei Zhang \\ Auburn University \\ International Trade Journal (2009) 301-29
}

The gap in total factor productivity in sawmills and wood preservation between the US and Canada generally increased from 1958 to 2005 . The present paper examines the effects of the various phases of the softwood lumber dispute, including relatively free trade, Canadian export taxes, and low and high countervailing duties, on this productivity gap. Exogenous control variables include US housing demand, the exchange rate, softwood lumber prices, and ratios of capital and nonproduction labor to labor. The effects of phases of the dispute on US imports from Canada are also examined. 


\section{PRODUCTIVITY AND TRADE DURING THE SOFTWOOD LUMBER DISPUTE}

The US and Canada are each other's largest trade partner and foreign investor, bilateral trade increasing $173 \%$ and bilateral foreign direct investment $226 \%$ between 1980 and 2005 . These increases were more pronounced following the Canada-US Free Trade Agreement (CUFTA) between the US and Canada in 1989 and the North American Free Trade Agreement (NAFTA) to include Mexico in 1994. Increased trade and investment are generally expected to encourage technology transfer and promote total factor productivity (TFP) convergence.

The present paper examines the effects of phases of the softwood lumber dispute on TFP and US lumber reports in error correction models. The paper focuses on trade in sawmills and wood preservation accounting for $70 \%$ of Canadian wood product revenue in 2005 and $26 \%$ of US revenue. One issue is the unintended consequence of US import restrictions increasing Canadian productivity. Determinants of US imports from Canada, including phases of the softwood lumber dispute, are also examined in an error correction model.

\section{A REVIEW OF THE LITERATURE ON TFP AND TRADE}

A substantial literature links trade and foreign investment to growth as in Parikh (2006). Asheghian (2004) finds foreign investment causes TFP growth as well as economic growth. Helleiner (1994) finds no conclusive relationship between the trade regime and TFP growth.

Cox and Harris (1986) and others predicted productivity convergence in North America prior to CUFTA and NAFTA. Bernard and Jones (1996) observe, however, at best weak labor productivity (LP) and TFP convergence in the OECD between 1970 and 1987. Bernard and Jensen (1999) uncover causality from productivity to exports but not vice versa, and find exports reallocate resources from less to more efficient plants. Carree, Klomp, and Thurik (2000) report mixed LP results for 28 manufacturing industries across 18 OECD countries between 1972 and 1992 and find knowledge and capital are barriers to productivity convergence. 
Trefler (2004) reports Canadian labor productivity gains of 14\% in export oriented industries and 15\% in import competing industries in CUFTA between 1980 and 1996. Rugman (2004) suggests the depreciating Canadian dollar provided an important stimulus to Canadian exports while TFP growth did not enhance the underlying relative competitiveness of Canadian exports between the mid 1970s and 2001. Rugman also notes the relative absence of price, wage, and rate of return convergence after CUFTA. There remains some debate over whether CUFTA has improved productivity in Canada. The relationship between US softwood lumber imports from Canada and the exchange rate, US lumber prices, and US housing demand has been studied. Adams, McCarl, and Homayounfarrokh (1986) and Roberts (1988) find US imports from Canada increase with an appreciating US dollar but Buongiorno, Chavas, and Uusivuori (1988) and Jennings, Adamowicz, and Constantino (1991) find no exchange rate effect while US lumber prices and housing demand do have effects. Sarker $(1993,1996)$ finds one long run cointegrating relationship among US lumber prices, US disposable income, US housing starts, US construction wages, and the exchange rate, these five factors accounting for $3 / 4$ of the variation in Canadian imports with most of the deviation from the long run equilibrium corrected in one quarter. Nagubadi and Zhang (2006) find competitiveness of the Canadian industry iss facilitated by its higher productivity and the US dollar appreciation before 1994 while only depreciation has an effect after 1994.

Nelson and Vertinsky (2004) bring out several structural and institutional differences between the US and Canada such as forestland ownership, forest policies, status of mills, mill capacity, and political economy. Stock market event studies such as Begley, Hughes, Rayburn, and Runkle (1998), Zhang and Hussain (2004), and Malhotra and Gulati (2006) have found significant impacts of the various trade regimes on softwood lumber producers or consumers. Gulati and Malhotra (2006) find trade diversion in exports from the Softwood Lumber Agreement (SLA) provinces. Weinstein (2004) notes overcapacity and falling prices during NAFTA may have been responsible for several sawmills shutting down, but the remaining mills were more efficient and Canadian firms maintained their share of the US market.

None of these studies have explicitly examined the impact of the various trade regimes or 
softwood lumber dispute phases on TFP growth or imports in the softwood lumber sector.

\section{A BRIEF HISTORY OF THE SOFTWOOD LUMBER DISPUTE}

The US and Canada trade freely for the most part but protection persists for softwood lumber.

With strong US housing demand and the depreciating Canadian dollar, the share of Canadian softwood lumber in US consumption increased from $10 \%$ in 1958 to $33 \%$ by 1983 , and to an all time high of $36 \%$ in 1996 before stabilizing at about 33\% as seen in Figures 1 and 2. Figure 1 shows how the Canadian share in the US softwood lumber consumption grew in tandem with the depreciating Canadian exchange rates over the period. Figure 2 presents paths of the exchange rate $E=C \$ / U S \$$ and US housing starts $(H)$. The US dollar generally appreciates over the period, lowering the price of imports except during the late 1980s and early 2000s. US housing starts appear to be highly cyclical, volatile, and stationary.

\section{* Figure $1 *$ Figure $2 *$}

The softwood lumber dispute dates back about 200 years as discussed by Reed (2001) and has passed through several distinct phases. The present analysis begins with relatively free trade between 1958 and 1982 followed by the four distinguishable periods of dispute in Zhang (2007),

$\begin{array}{lll}\text { Lumber I } & 1958-86 & \text { Relatively free trade } \\ \text { Lumber II } & 1987-91 & \text { Canadian export tax } \\ \text { Lumber III } & 1992-94 & \text { Low countervailing duty } \\ \text { SLA } & 1996-00 & \text { Tariff rate quota }\end{array}$

Lumber IV 2001-05 High countervailing duty and anti-dumping duty

Figure 3 shows the US softwood lumber production, consumption, Canadian imports, its share in the US consumption, and the dispute phases over the study period. Free trade in Lumber I included US appeals for protection against Canadian softwood lumber imports in 1982 under the US countervailing duty law, alleging that various Canadian forest management and stumpage practices amounted to subsidies. After an investigation by the US Department of Commerce, the countervailing duty (CVD) was denied. During this relatively free trade period from 1958 to 1986, the US consumption and production 
increased by $57.3 \%$ and $28.8 \%$ respectively, while Canadian imports rose by $358 \%$ (3.1 bbf to 14.1 bbf) and its share in the US consumption by $191 \%(10.3 \%$ to $30 \%)$.

*Figure $3 *$

Lumber II began with another CVD petition and after preliminary investigation an interim CVD was imposed. Subsequent negotiations resulted in a Memorandum of Understanding (MOU) with the CVD transformed to an equivalent Canadian export tax designed to increase the costs of Canadian lumber and reduce any subsidy advantage (Wear and Lee 1993). CUFTA began in 1989 and Lumber II ended when Canada unilaterally withdrew from the MOU in September 1991. During this period from 1987 to 1991, the US consumption and production declined by $16.8 \%$ and $13.1 \%$, while Canadian imports and its share declined by $21.6 \%$ and $6.1 \%$.

Lumber III began when the Department of Commerce self initiated a new CVD investigation and a CVD of 6.5\% was applied in July 1992 beginning a three year CUFTA dispute settlement and a period of free trade between 1994 and 1996. This period of low CVD, from 1992 to 1994, saw 6.9\% increase in the US consumption, but $1.2 \%$ decline in the US production, while Canadian imports registered an increase of $21.6 \%$ and its share by $13.8 \%$. However in 1995 , which was in effect a free trade period, the US consumption increased by $5.5 \%$, but production declined by $6.7 \%$. In that same year, Canadian imports and its share shot up dramatically by $28.5 \%$ and $21.8 \%$ respectively.

The Softwood Lumber Agreement (SLA) of 1996 imposed a tariff rate quota system. The SLA stipulated an annual duty free quota of 14.7 billion board feet (bbf) of lumber with increasingly prohibitive tariff rates (for quantities above duty free quota) that lasted until March 2001. The SLA period from 1996 to 2000 saw the US consumption and production up by $9.1 \%$ and $8.1 \%$, while Canadian imports increased by $2.9 \%$, but its share declined by $5.7 \%$.

Lumber IV began in 2001 as the US imposed an interim CVD as well as interim anti-dumping duties (ADD) amounting to 27\%. The final combined CVD and ADD of $20 \%$ were applied to most imports after May 2002 although these were reduced to 11\% in 2003. In October 2006 a new SLA 
stipulated an export tax ranging up to $15 \%$ or an export charge up to $5 \%$ plus volume control for a period of up to 9 years. Between 2001 and 2005, a period of high CVD and ADD, the US consumption and production increased by $19.9 \%$ and $17.6 \%$, while Canadian imports increased by $15.5 \%$, but its share was down by $3.7 \%$.

The dispute settlement mechanism failed at every stage. Canada has challenged US decisions at several stages in CUFTA, NAFTA, and the World Trade Organization (WTO). Canada has won several major legal challenges especially under NAFTA while the US has some success with WTO. Braudo and Trebilcock (2002) point out the institutional failure of the NAFTA dispute settlement process. Froese (2006) believes that dispute settlement has been ineffective because Canada is a small economy facing the challenge of enforcing panel decisions while the US chooses to avoid compliance.

\section{THEORY AND SPECIFICATION OF THE TFP GROWTH GAP AND IMPORTS}

TFP growth is driven by more efficient utilization of inputs and technology, and free trade is expected to increase competition and diminish any TFP gap between countries. Firms protected by import restrictions might lax into inefficiency.

For the present analysis, the general production function is

$$
Y=f\left(K, L_{P}, L_{N}, E, M\right)
$$

where $Y$ is output, $K$ capital, $L_{P}$ production labor, $L_{N}$ non-production labor, $E$ energy, and $M$ material input. Assume a translog production function, essentially a quadratic function in natural logs. The six lumber outputs in the data are softwood lumber, hardwood lumber, wood chips, wood preservation products, shingles \& shakes, and other lumber products.

The production function predicts output based on inputs. TFP is the residual between actual and predicted outputs

$$
T F P=Y-Y_{p}
$$

TFP growth $\left(\mathrm{TFP}_{\mathrm{G}}\right)$ is the difference between weighted growth rates of output and inputs and is computed using the Törnqvist-Theil index that Diewert (1976) shows is exact and superlative, 


$$
T F P_{G}=T F P_{t} / T F P_{-1}=\exp \left[\Sigma^{m} .5\left(R_{j t}+R_{j-1}\right) \ln \left(Y_{j t} / Y_{j-1}\right)-\Sigma^{n} .5\left(S_{i t}+S_{i-1}\right) \ln \left(X_{i t} / X_{i-1}\right)\right]
$$

where $\mathrm{m}=6$, the number of outputs, $\mathrm{n}=5$, the number of inputs, $R_{j t}$, the revenue share of output $j$ at time $t, S_{i t}$, the cost share of input $i$ at time $t$, and $X_{i t}$, the input of factor $i$ at time $t$. The $T_{F P}$ index is computed as a chained index relative to the base year 1958 .

For predicting growth, $T F P_{G}$ is assumed to be a linear function of capital/labor ratio $K / L$, the ratio of skilled labor to labor (nonproduction labor/total labor) $L_{N} / L$, the exchange rate $E=C \$ / \$$, US housing starts $(H)$, and dummy variables $D$ indicating various phases of the lumber dispute,

$$
T F P_{G}=f\left(K / L, L_{N} / L, E, H, D\right) \text {. }
$$

Dummy variables are $\mathrm{D}_{\text {II }}$ for Lumber II, $\mathrm{D}_{\text {III }}$ for Lumber III, $\mathrm{D}_{\mathrm{SLA}}$ for the SLA, and $\mathrm{D}_{\text {IV }}$ for Lumber IV. The intercept represents free trade period that includes Lumber I (see Figure 3). For K/L and $\mathrm{H}$ the expected signs are positive while there is no clear expectation for $L_{N} / L$. An appreciating US dollar relaxes competition suggesting a negative effect of $\mathrm{E}$ in the US, and a positive effect in Canada.

The productivity gap is specified as

$$
\Delta T F P_{G}=f\left(\Delta K / L, \Delta L_{N} / L, E, H, D\right)
$$

where $\Delta$ is the difference between the US and Canada. The clear expected signs are positive for $\Delta K / L$ and negative for $E$. The expected effect of $\Delta L_{N} / L$ is not clear as is the expected effect of $H$ that might stimulate $T_{F P}$ in both countries and its expected effect is negative.

To examine the influence on imports, consider the function

$$
M=f\left(E, H, P_{m}, P_{d}, D\right)
$$

where $M$ is the quantity of $\mathrm{U}$ imports, $P_{m}$ the price of Canadian imported softwood lumber, and $P_{d}$, the US domestic price. Expected signs are positive for $E, H$, and $P_{d}$, and negative for $P_{m}$.

Augmented Dickey-Fuller (ADF) tests for unit roots determine the stationarity of various variables as in Enders (1995). Multivariate cointegration tests explore whether the series have common stochastic trends as suggested by (Johansen 1988; 1995). Trace and maximum eigenvalue test statistics find the cointegration rank. Cointegrated variables may contain some linear combination that is stationary, 
indicating a stochastic trend. If variables are cointegrated, equations (4) to (6) are estimated with error correction models (ECMs) to allow for long term adjustment. If variables are not cointegrated, a vector autoregression VAR method is utilized.

\section{DATA ON SOFTWOOD PRODUCTION AND TRADE}

Annual data covers 1958 to 2005 . For the period 1958 to 1996, the US industries are Standard Industrial Classification SIC 2421 Sawmills and Planing mills, SIC 2429 Special Products Sawmills, and SIC 2491 Wood Preserving, and for the period 1997 to 2005 North American Industry Classification System NAICS code 321113 Sawmills and 321114 Wood Preservation. Sources of US data are the Annual Survey of Manufactures and the Census of Manufacturing.

Corresponding industries for Canada are SIC 2512/2513 Sawmills and Planing Mill Products, SIC 2511 Shingle \& Shake Mills, and SIC 2591 Wood Preservation for the period 1961 to 1996, and NAICS 321111 Sawmills except Shingle \& Shake Mills, 321112 Shingle \& Shake Mills, and 321114 Wood Preservation from 1997 to 2005. Sources of data are Annual Census of Manufactures and Statistics Canada Catalogues 35-204 and 35-250.

Outputs (softwood, hardwood, woodchips, wood preservation products, wood-ties-shingles-shakes, and other lumber products) are imputed from the value of shipments using prices derived from quantities and revenues. The capital stock is in millions of dollars converted to constant 2001 dollars in each currency with respective GDP deflators. The unit for labor input is hours worked. The unit for energy is the British thermal units Btu. Material inputs are in thousand board feet MBF but include nonwood materials such as chemicals and contract work, and are represented as equivalent quantities by dividing expenditure on nonwood materials by wood material prices. In the few cases of unavailable data, interpolation fills the gaps. A complete description of the data is in the Appendix of Nagubadi and Zhang (2006).

Annual housing starts and the $\mathrm{C} \$ / \$$ exchange rate are from the website of the St. Louis Federal Reserve Bank. The US softwood lumber price index is from the Bureau of Labor Statistics, and the data 
on Canadian softwood lumber prices from Statistics Canada.

\section{COINTEGRATION ANALYSIS FOR SOFTWOOD MARKET VARIABLES}

The TFP growth indices in Figure 4 generally diverge since 1966 nearly converging in 1993 but then diverging more. The TFP gap reaches its highest level in 1998, appears to close in 2004, but increases again in 2005. Overall growth rates of TFP are $1.22 \%$ in the US and $0.66 \%$ in Canada. Figure 4 indicates the TFP gap has increased in line with most manufacturing industries as shown by Eldridge and Sherwood (2001) and Bernstein, Harris, and Sharpe (2002).

* Figure $4 *$

Capital deepening should raise productivity and Figure 5 shows time trends of $K / L$ ratios. The $K / L$ ratio is consistently lower in Canada but rises with decreased employment during the oil crisis of 1974-75, the housing market collapse of 1981-82, and the recession after Gulf War I in 1991-2. The difference $\Delta K / L$ moves in waves.

* Figure $5 *$

The ratio of skilled labor to labor $L_{N} / L$ is higher in Canada until 1991 but declines as seen in Figure 6, while the US ratio has generally increased. The difference $\Delta L_{N} / L$ between the US and Canada has generally increases.

$$
\text { * Figure } 6 *
$$

Table I presents the ADF unit root tests. Equations with a significant constant or trend are retained. Lag length is selected with the Schwartz Information Criterion (SIC). The Durbin-Watson (DW) statistics for most tests indicate a lack of autocorrelation. Except for US housing starts $\mathrm{H}$ and the TFP growth gap, all series exhibit unit roots and are stationary in first differences.

* Table I*

Johansen's multivariate cointegration tests are applied to $\Delta T F P_{G}, \Delta K / L$, and $\Delta L_{N} / L$ to check for cointegration. The null hypothesis of no cointegration is accepted in Tables II and III according to both trace and maximum-eigenvalue statistics. There is no long run equilibrium between variables, and each 
variable has its own stochastic trend. When variables are nonstationary and not cointegrated, vector autoregression (VAR) can capture short run relationships.

$$
\text { * Table II * Table III * }
$$

Table IV presents the VAR models with one lag for the $T F P_{G}$ indices, explaining $88 \%$ and $77 \%$ of the variation for the US and Canada. The exchange rate E and US housing starts $\mathrm{H}$ are insignificant and removed. The lagged $T F P_{G}$ and the lagged $L_{N} / L$ have significant and positive impact for the US. Coefficients for the lagged $T F P_{G}$ and lagged $K / L$ have positive effect for Canada. Note that the lagged $K / L$ increases TFP growth in Canada but not in the US. Trade restrictions during the last phase (L $\mathrm{L}_{\mathrm{IV}}$ ) significantly increased $T_{F P}$ in both the US and Canada, while the other phases have no impact.

* Table IV *

Regarding the TFP gap Johansen's cointegration test reported in Table V rejects the null hypothesis of no cointegration. There is at most one cointegration relationship or long run equilibrium among the five variables. This implies that there are four stochastic trends in the system moving four different ways from the long run equilibrium relationship.

* Table V*

\section{ERROR CORRECTION MODEL OF THE TFP GAP}

The ECM in Table VI indicates a significant error correction process. Among the exogenous variables only lagged $\Delta L_{N} / L$ has any effect, lowering the TFP gap and it also has a negative effect through the error correction process. The implication is that an increasing share of production workers in the labor force raises TFP in both countries. The capital/labor gap $\Delta(K / L)_{-1}$ has a positive impact through the error correction process implying that increases in the capital/labor ratio raise productivity in both countries as expected.

The negative and significant coefficients for the phase dummy variables $\left(\mathrm{L}_{\mathrm{II}}\right.$ and $\left.\mathrm{L}_{\mathrm{III}}\right)$ indicate the various trade restrictions have helped to reduce the TFPG gap. This result is consistent with popular media reports (e.g., The Economist 2003; Washington Post 2003): restrictive duties have forced Canadian 
producers to be more efficient and fitter than before. The duties certainly hit Canada hard. But as production is now concentrated at the more efficient mills, Canadian firms maintained their share of the American market while still turning a thin profit. As the duties make the US producers oversupply, bring products from non-Canadian sources, and encourage the use of lumber substitutes, which together mitigate the initial price increase caused by the duties, they do not protect American producers as much as they have hoped in the long run (Zhang 2007).

* Table VI *

\section{ECM FOR U.S. IMPORTS FROM CANADA}

The Johansen cointegration test in Table VII indicates three cointegration relationships according to the trace statistic but two by the maximum eigenvalue test. Two error correction terms are included in the ECM for imports M in Table VIII. The second cointegrating equation is a significant error correction process. Among the endogenous variables, the lagged difference in US housing starts has a positive on the quantity of imports $\mathrm{M}$ effect offset somewhat by the error correction process with the net effect calculated as $0.52=0.70-(0.41 \times 0.44)$. Increased US housing demand increases the level of imports.

$$
* \text { Table VII * and * Table VIII * }
$$

The lagged exchange rate has no effect on the quantity of imports suggesting that Canadian producer's price to market offsetting changes in the exchange rate with a change in their own price. Canadian producers may also inventory and do some business in US dollars.

Prices in Canada and the US have their expected effects through the error correction process. A higher lagged price in Canada $\left(P_{m-1}\right)$ lowers US imports with an error correction coefficient of $-0.36=$ $0.41 \mathrm{x}-0.90$, while a higher lagged price in the US $\left(P_{d-1}\right)$ raises imports with the coefficient $0.30=0.41 \mathrm{x}$ 0.77 .

The positive constant 0.10 in Table VIII indicates a positive effect on the US imports during the free trade period that also included Lumber I. Coefficients for the phase dummies indicate that Lumber II, SLA, and Lumber IV have significantly lowered imports relative to the free trade period. Compared to the 
free trade period imports did fall, however, with the Canadian export tax during Lumber II $(0.10-0.12=-$ 0.02), while the high CVD and ADD during Lumber IV had no effect on Canadian imports $(0.10-0.10=$ $0)$.

\section{CONCLUSION}

Protection may have the unintended consequence of lowering domestic productivity for US firms, and the productivity gap between US and Canadian softwood lumber producers diminished under Lumber II (MOU) from 1987 to 1991, and under low countervailing duties of Lumber III from 1991 to 1994. The exchange rate and US housing starts have no effect on the productivity gap, while capital/labor ratios raise productivity as do higher shares of production workers.

US trade restrictions have generally been able to diminish Canadian imports relative to the free trade period of 1958 to 1986 , except during the low countervailing duty period of 1992 to 1994 (Lumber III). Higher US housing demand significantly increases imports, while the exchange rate has no effect, perhaps due to pricing to market or currency substitution. As expected, imports increase with lower softwood lumber prices in Canada and higher prices in the US.

The present significant effects of phases of the softwood lumber dispute suggest studies not including the trade regime would be incorrectly specified. The major conclusion regarding productivity is that various trade restrictions had the unintended consequence of lowering the US relative productivity. Except for the low countervailing period of Lumber III, the trade restrictions have succeeded in lowering the imports compared to free trade period. However, the net effect of export tax regime of Lumber II is negative. On the other hand, the trade regimes of Lumber III and SLA have a net positive effect similar to free trade, while the trade regime of Lumber IV has no effect on the imports. 


\section{REFERENCES}

Adams, D.M., McCarl, B.A., and Homayounfarrokh, L. 1986. The Role of Exchange Rates in CanadianUS Lumber Trade. Forest Science 32:973-88.

Asheghian, P. 2004. Determinants of Economic Growth in the United States: The Role of the Foreign Direct Investment. The International Trade Journal 18(1):63-83.

Begley, J., Hughes, J., Rayburn, J., and Runkle, D. 1998. Assessing the Impact of Export Taxes on Canadian Softwood Lumber. The Canadian Journal of Economics, 31(1):297-219.

Bernard, A.B., and Jones, C.I. 1996. Productivity across Industries and Countries: Time Series Theory and Evidence. Review of Economics and Statistics 78:135-46.

Bernard, A.B., and Jensen, J.B. 1999. Exporting and Productivity. Working Paper 7135, National Bureau of Economic Research.

Bernstein, J.I., Harris, R.G., and Sharpe, A. 2002. The Widening Canada-US Manufacturing Productivity Gap. International Productivity Monitor Fall:3-22.

Braudo, R. J., and Trebilcock, M. 2002. The Softwood Lumber Saga: Implications for Canada's Future Trade Strategy. Mimeo, University of Toronto.

Buongiorno, J., Chavas, J.P., and Uusivuori, J. 1988. Exchange Rates, Canadian Lumber Imports, and US Prices: A Time Series Analysis. Canadian Journal of Forest Research 18:1587-94.

Carree, M.A., Klomp, L., and Thurik, A.R. 2000. Productivity Convergence in OECD Manufacturing Industries, Economics Letters 66:337-45.

Cox, D., and Harris, R.G. 1986. A Quantitative Assessment of the Economic Impact on Canada of Sectoral Free Trade with the US. The Canadian Journal of Economics 9:377-94.

Diewert, W.E. 1976. Exact and Superlative Index Numbers. Journal of Econometrics 4: 115-45.

Eldridge, L.P., and Sherwood, M.K. 2001. A Perspective on the US-Canada Manufacturing Productivity Gap. Monthly Labor Review February:21-48.

Enders, W. 1995. Applied Econometric Time Series. New York: John Wiley \& Sons, Inc. 433p.

Froese, M.D. 2006. Contingent Protection Measures and the Management of the Softwood Lumber Trade in North America. The Estey Centre Journal of International Law and Trade Policy 7(2):126-151.

Gulati, S., and Malhotra, N. 2006. Estimating Export Response in Canadian Provinces to the Canada-US Softwood Lumber Agreement. Canadian Public Policy XXXII(2):157-171.

Helleiner, G.K. 1994. Introduction. In G.K. Helleiner (ed.) Trade policy and industrialization in turbulent times. London: Routledge, pp.1-16. 
Jennings, S., Adamowicz, W., and Constantino, L. 1991. The Canadian Lumber Industry and the Macroeconomy: A Vector Autoregression Analysis. Canadian Journal of Forest Research 21:28899.

Johansen, S. 1988. Statistical Analysis of Cointegrating Vectors. Journal of Economics Dynamics and Control 12:231-54.

Johansen, S. 1995. Likelihood-based Inference in Cointegrated Vector Auto-regressive Models. Oxford University Press.

Malhotra, N., and Gulati, S. 2006. The Users of Lumber and the US-Canada Softwood Lumber Agreement: An Event Study. Mimeo, Vancouver: University of British Columbia.

McKinney, J.A. 2004. Political Economy of the US-Canada Softwood Lumber Dispute. CanadianAmerican Public Policy No. 57.

Nagubadi, R.V., and Zhang, D. 2006. Competitiveness in the Sawmills and Wood Preservation Industry in the United States and Canada. Forest Science 52(4):340-352.

Nelson, H., and Vertinsky, I. 2004. The Canada-US Softwood Lumber Disputes. Pp.237-262 in Rugman, A.M. (ed.).

Parikh, A. 2006. Relationship between Trade Liberalization, Growth, and Balance of Payments in Developing Countries: An Econometric Study. The International Trade Journal 20(4):429-467.

Reed, L. 2001. Two Centuries of Softwood Lumber War between Canada and the United States: A Chronicle of Trade Barriers viewed in the Context of Saw Timber Depletion. Prepared for The Free Trade Lumber Council, Montreal, Canada.

Roberts, D. 1988. The Impact of Exchange Rate Changes on the Canadian Forest Products Sector. Economics Branch Working Paper, Forestry Canada.

Rugman, A.M. (ed.) 2004. North American Economic and Financial Integration. Research in Global Strategic Management. Volume 10, Elsevier Ltd., 358p.

Rugman, A.M. 2004. North American Intra-Regional Trade and Foreign Direct Investment. Pp.3-16 in Rugman (ed.).

Sarker, R. 1993. A Maximum Likelihood Cointegration Analysis of Canadian Lumber Exports. Canadian Journal of Agricultural Economics 41:97-110.

Sarker, R. 1996. Canadian Softwood Lumber Exports to the US: A Cointegrated and Error Corrected System. Journal of Forest Economics 2:205-31.

The Economist. 2003. A Simple Lesson in Economics: The Softwood Lumber Dispute. February 1, 366(8309):49. 
Trefler, D. 2004. The Long and Short of the Canada-US Trade Agreement. The American Economic Review 94(4):870-895.

Washington Times. 2003. Eluding Tariffs; Firms Look at Options in Steel, Lumber Trade. January 20. C13.

Wear, D.N., and Lee, K.J. 1993. US Policy and Canadian Lumber: Effects of the 1986 Memorandum of Understanding. Forest Science 39(4):799-815.

Weinstein, B.L. 2004. Has NAFTA Fulfilled its Promise? Pp.339-348, in Rugman (ed.).

Zhang, D. 2007. The Softwood Lumber War: Politics, Economics and the Long US-Canada Trade Dispute. Resources for the Future Press. Washington, DC. 300p.

Zhang, D., and Hussain, A. 2004. Impact of US-Canada Softwood Lumber Trade Dispute on Forest Products Companies: A Stock Market Perspective. Mimeo, School of Forestry, and Wildlife Sciences, Auburn University, Alabama. 
Figure 1

Canadian Share in the US Softwood Lumber Consumption and the $C \$ / \$$ Exchange Rate

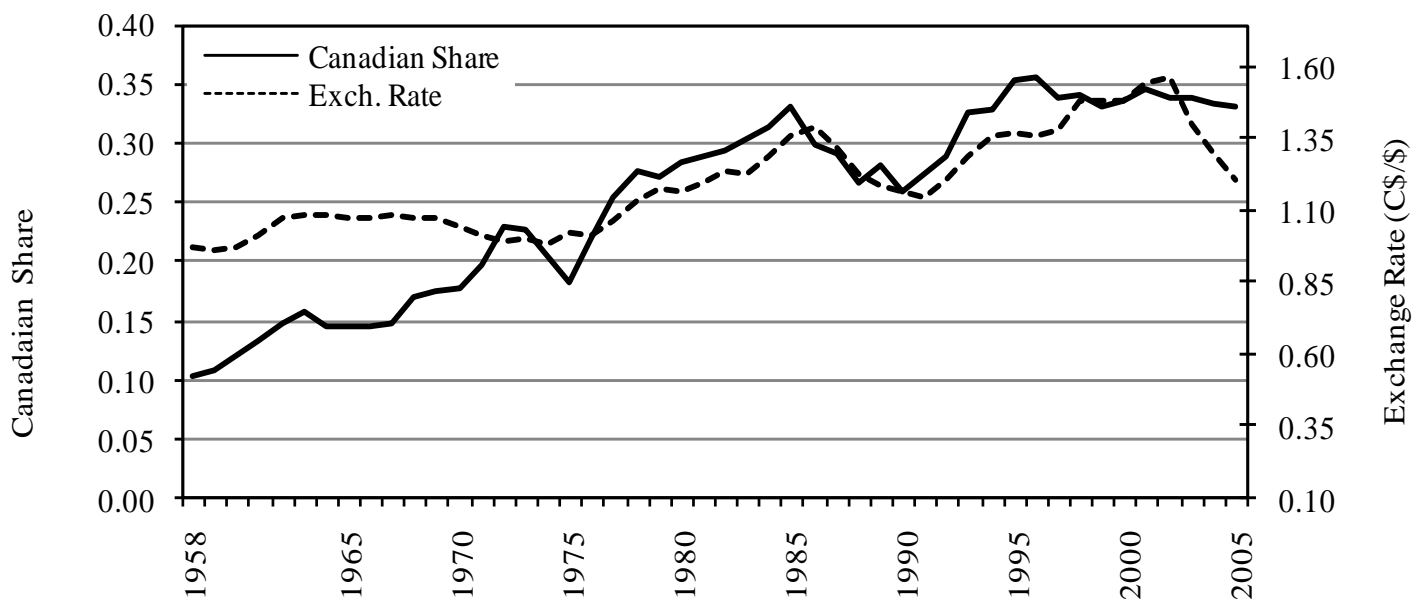

Figure 2

US Housing Starts and the $\mathbf{C} \$ \mathbf{\$}$ Exchange Rate

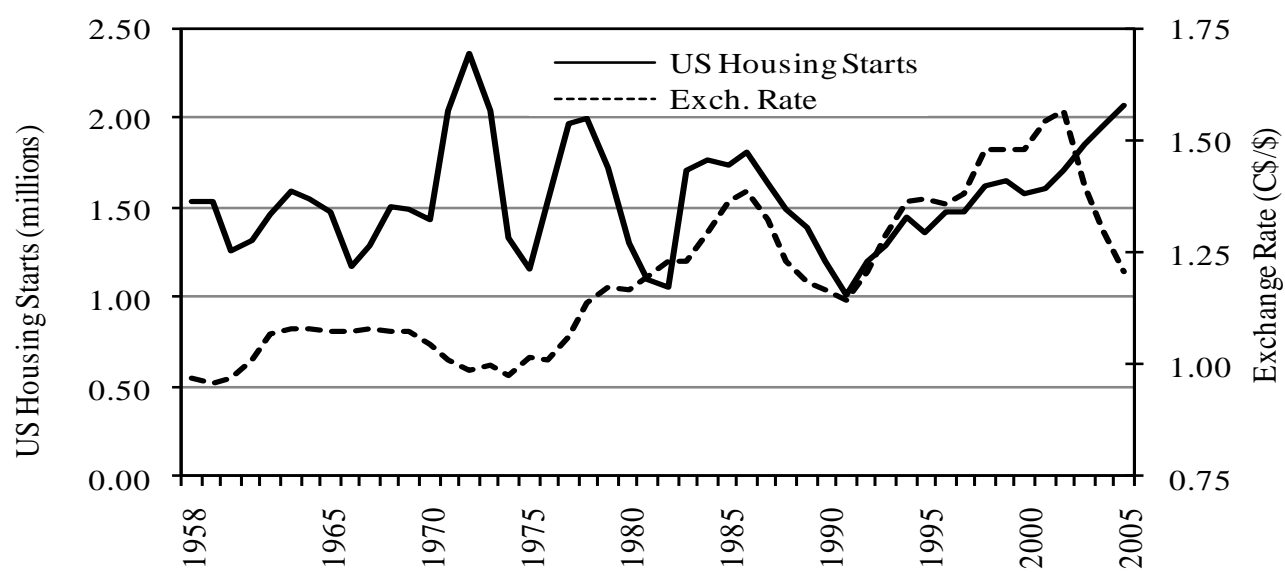


Figure 3

US Softwood Production, Consumption, Canadian Imports, its Share, and Dispute Phases

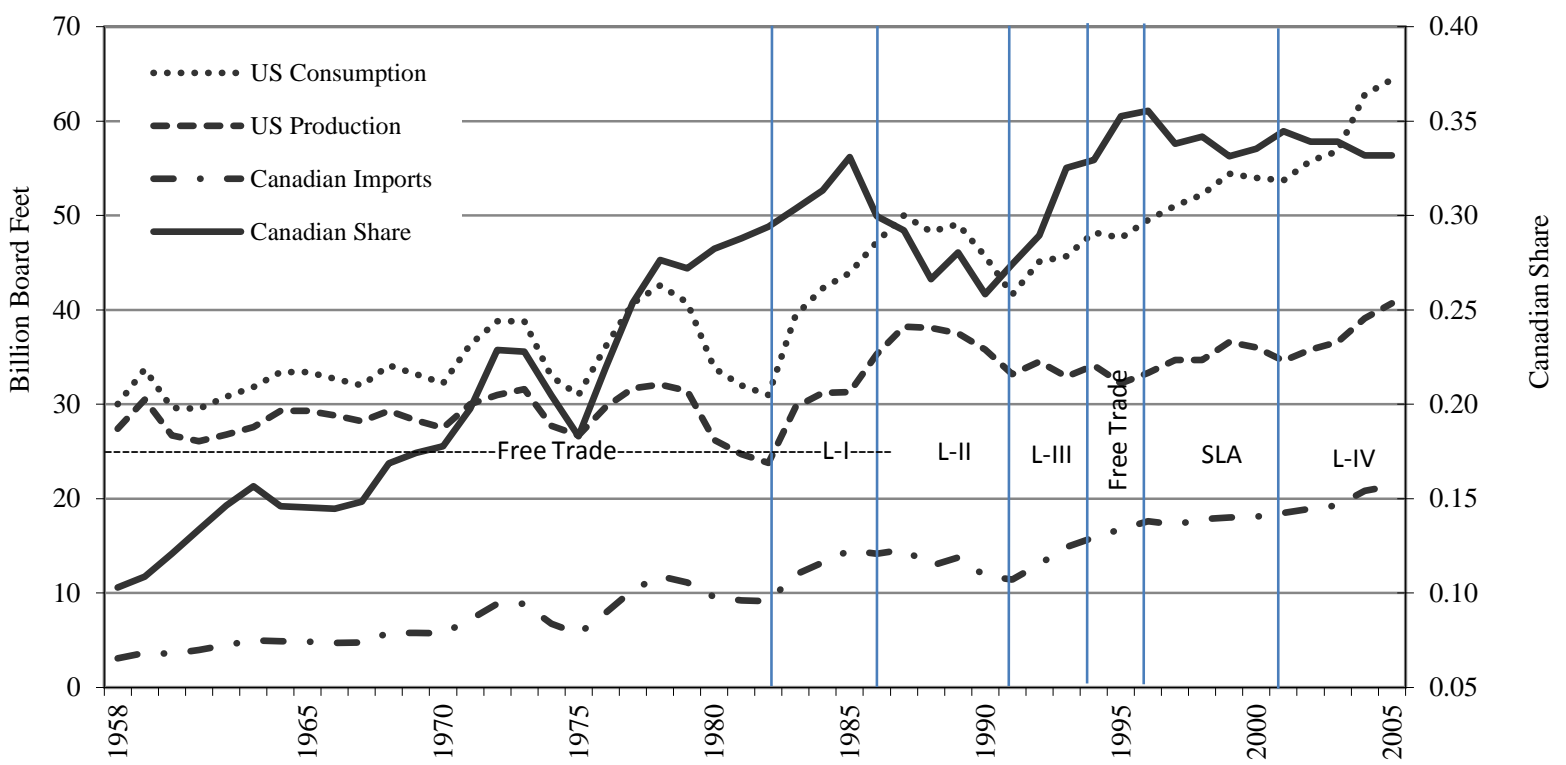

Figure 4

TFP Indices

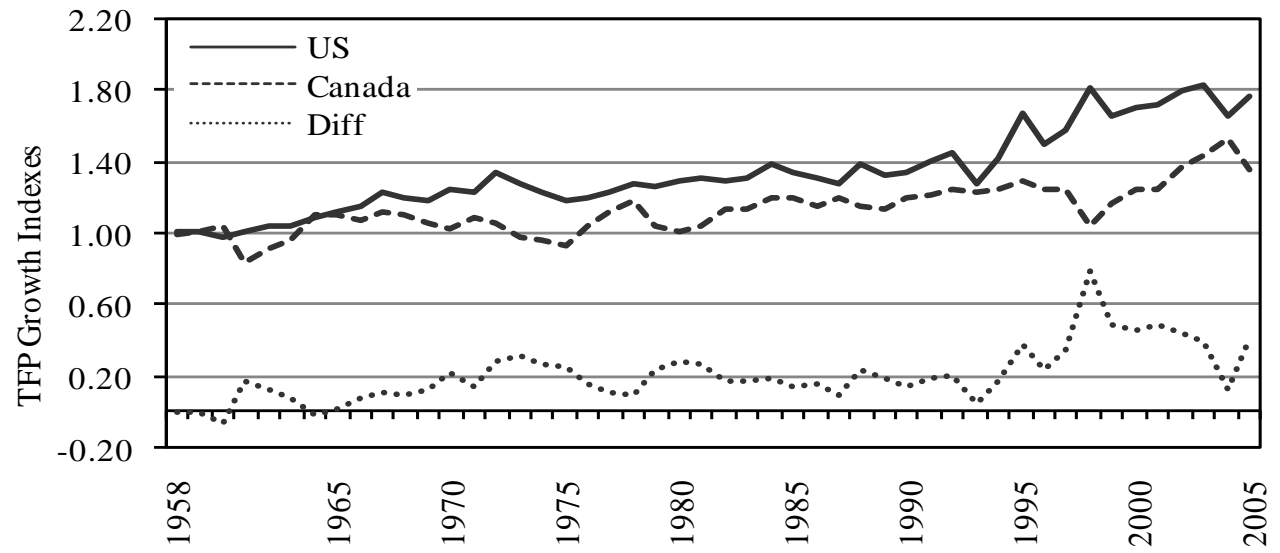


Figure 5

K/L Ratios

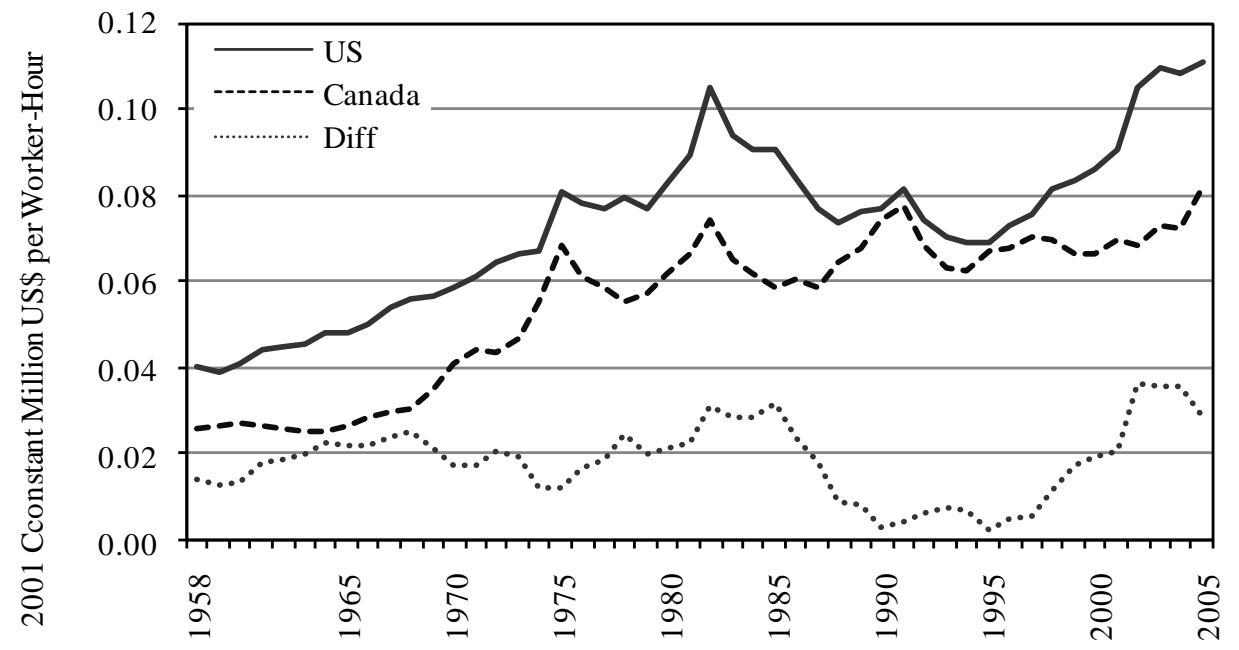

Figure 6

$\mathbf{L}_{\mathbf{N}} / \mathrm{L}$ Ratios

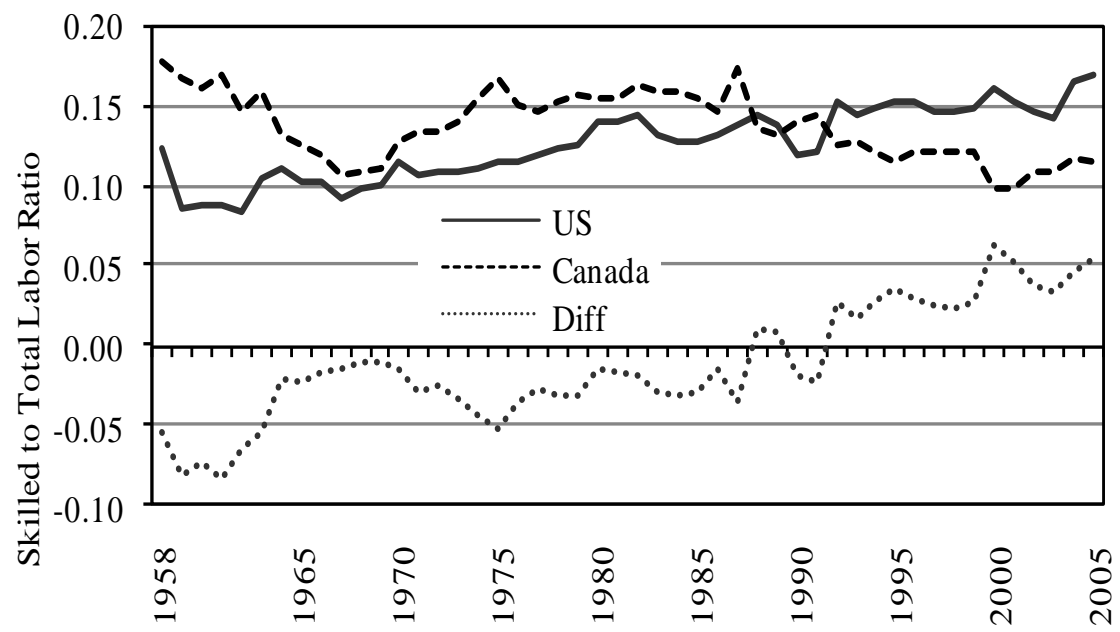


Table I

Augmented Dickey-Fuller (ADF) Tests

\begin{tabular}{|c|c|c|c|c|c|c|}
\hline \multirow[t]{2}{*}{ Variables } & \multicolumn{3}{|c|}{ Levels } & \multicolumn{3}{|c|}{ First-difference } \\
\hline & Lags $^{a}$ & $\mathrm{ADF}$ & $\mathrm{DW}^{\mathrm{b}}$ & Lags & $\mathrm{ADF}$ & DW \\
\hline $\mathrm{TFPG}_{\mathrm{US}}$ & $2(\mathrm{c}, \mathrm{t})$ & -1.33 & 1.88 & 1(c) & $-9.84 * *$ & 1.92 \\
\hline TFPG $_{\mathrm{CN}}$ & $0(\mathrm{c})$ & -1.79 & 1.92 & $0(\mathrm{c})$ & $-6.92 * *$ & 1.92 \\
\hline Diff TFPG US-CN & $0(\mathrm{c})$ & $-3.01 *$ & 2.16 & 1(c) & $-7.52 * *$ & 1.82 \\
\hline $\mathrm{K} / \mathrm{L}_{\mathrm{US}}$ & $0(\mathrm{c})$ & -0.62 & 1.72 & $0(\mathrm{c})$ & $-5.87 * *$ & 1.99 \\
\hline $\mathrm{K} / \mathrm{L}_{\mathrm{CN}}$ & $2(\mathrm{c}, \mathrm{t})$ & -2.29 & 1.91 & 2(c) & $-5.28 * *$ & 1.94 \\
\hline Diff $\mathrm{K} / \mathrm{L}_{\text {US-CN }}$ & $1(\mathrm{c})$ & -1.59 & 1.55 & $0(\mathrm{c})$ & $-5.51 * *$ & 1.96 \\
\hline $\mathrm{L}_{N} / \mathrm{L}_{\mathrm{US}}$ & $0(\mathrm{c})$ & -1.08 & 1.72 & 2(c) & $-5.91 * *$ & 2.22 \\
\hline $\mathrm{L}_{N} / \mathrm{L}_{\mathrm{CN}}$ & $0(\mathrm{c})$ & -2.36 & 2.31 & 1(c) & $-5.42 * *$ & 1.97 \\
\hline Diff $\mathrm{L}_{\mathrm{N}} / \mathrm{L}_{\mathrm{US}-\mathrm{CN}}$ & $0(\mathrm{c}, \mathrm{t})$ & -3.13 & 1.90 & 1(c) & $-6.14 * *$ & 2.03 \\
\hline $\ln M$ & $3(\mathrm{c})$ & -1.51 & 2.11 & 2(c) & $-6.58 * *$ & 2.10 \\
\hline $\ln H_{\text {US }}$ & $1(\mathrm{c})$ & $-4.91 * *$ & 1.83 & 2(c) & $-6.15^{* *}$ & 2.07 \\
\hline $\operatorname{lnE}$ & $1(\mathrm{c})$ & -2.26 & 1.87 & 0 (c) & $-3.38 *$ & 1.78 \\
\hline $\ln \mathrm{P}_{\mathrm{CN}}$ & $0(\mathrm{c})$ & -1.23 & 1.95 & 0 (c) & $-6.46^{* *}$ & 1.96 \\
\hline $\ln \mathrm{P}_{\mathrm{US}}$ & $0(\mathrm{c})$ & -0.94 & 1.86 & $0(\mathrm{c})$ & $-6.19 * *$ & 1.93 \\
\hline
\end{tabular}

${ }^{a}$ Schwartz Information Criterion (SIC). Letters in parenthesis indicate exogenous variables in the equation estimating the $\mathrm{ADF}$ statistic, $\mathrm{c}=$ constant, and $\mathrm{t}=$ trend.

${ }^{\mathrm{b}}$ Durbin-Watson statistic.

$* *$, and $*$ denote rejection of null hypothesis of a unit root at $1 \%$ and $5 \%$ significance levels 
Table II

Johansen's Multivariate Cointegration Test for the US TFP

\begin{tabular}{lcccccc}
\hline $\begin{array}{c}\text { Null } \\
\text { Hypothesis }\end{array}$ & $\begin{array}{c}\text { Eigen- } \\
\text { value }\end{array}$ & $\begin{array}{c}\text { Trace } \\
\text { Statistic }\end{array}$ & $\begin{array}{c}\text { 5 Percent } \\
\text { Critical Value }\end{array}$ & $\begin{array}{c}\text { Max-Eigen } \\
\text { Statistic }\end{array}$ & $\begin{array}{c}\text { 5 Percent } \\
\text { Critical Value }\end{array}$ & $\begin{array}{c}\text { Hypothesized } \\
\text { No. of CE(s) }\end{array}$ \\
\hline & & & & & & \\
$\mathrm{H}_{\mathrm{o}}: \mathrm{r}=0$ & 0.37 & 27.77 & 29.80 & $21.43^{*}$ & 21.13 & None \\
$\mathrm{H}_{\mathrm{o}}: \mathrm{r} \leq 1$ & 0.13 & 6.33 & 15.49 & 6.29 & 14.26 & At most 1 \\
$\mathrm{H}_{\mathrm{o}}: \mathrm{r} \leq 2$ & 0.001 & 0.04 & 3.84 & 0.04 & 3.84 & At most 2
\end{tabular}

Trace test indicates no cointegration and Max-Eigen value test indicates one cointegration at $5 \%$.

Variables included are $\mathrm{TFP}_{\mathrm{G}}$ index, $\mathrm{K} / \mathrm{L}$ ratio, and $\mathrm{L}_{\mathrm{N}} / \mathrm{L}$ for the US.

Table III

Johansen's Multivariate Cointegration Test for Canada $\mathbf{T F P}_{\mathrm{G}}$

\begin{tabular}{lcccccc}
\hline $\begin{array}{c}\text { Null } \\
\text { Hypothesis }\end{array}$ & $\begin{array}{c}\text { Eigen- } \\
\text { value }\end{array}$ & $\begin{array}{c}\text { Trace } \\
\text { Statistic }\end{array}$ & $\begin{array}{c}\text { 5 Percent } \\
\text { Critical Value }\end{array}$ & $\begin{array}{c}\text { Max-Eigen } \\
\text { Statistic }\end{array}$ & $\begin{array}{c}\text { 5 Percent } \\
\text { Critical Value }\end{array}$ & $\begin{array}{c}\text { Hypothesized } \\
\text { No. of CE(s) }\end{array}$ \\
\hline $\mathrm{H}_{\mathrm{o}}: \mathrm{r}=0$ & 0.28 & 21.89 & 29.80 & 15.27 & 21.13 & None \\
$\mathrm{H}_{\mathrm{o}}: \mathrm{r} \leq 1$ & 0.11 & 6.62 & 15.49 & 5.12 & 14.26 & At most 1 \\
$\mathrm{H}_{\mathrm{o}}: \mathrm{r} \leq 2$ & 0.03 & 1.50 & 3.84 & 1.50 & 3.84 & At most 2
\end{tabular}

Both Trace test and Max-Eigen value test indicate no cointegration at $5 \%$.

Variables included are $\mathrm{TFP}_{\mathrm{G}}$ index, $\mathrm{K} / \mathrm{L}$ ratio, and $\mathrm{L}_{\mathrm{N}} / \mathrm{L}$ for Canada.

Table IV

VAR Model Estimates for the TFP $_{\mathrm{G}}$

\begin{tabular}{|c|c|c|c|c|}
\hline \multirow{2}{*}{ Variables } & \multicolumn{2}{|c|}{ U.S. TFP $_{\mathrm{G}}$} & \multicolumn{2}{|c|}{ Canada TFP $_{\mathrm{G}}$} \\
\hline & Coefficient & t-value & Coefficient & t-value \\
\hline $\mathrm{TFP}_{\mathrm{G}-1}$ & $0.574 * * *$ & 3.22 & $0.479 * * *$ & 3.57 \\
\hline $\mathrm{K} / \mathrm{L}_{-1}$ & 0.579 & 0.41 & $1.913 * *$ & 2.14 \\
\hline $\mathrm{L}_{N} / \mathrm{L}_{-1}$ & $1.977^{\dagger}$ & 1.66 & -0.769 & -1.09 \\
\hline Constant & $0.269^{\dagger}$ & 1.54 & $0.584 * * *$ & 3.15 \\
\hline $\mathrm{D}_{\mathrm{II}}$ & 0.007 & 0.14 & 0.023 & 0.59 \\
\hline $\mathrm{D}_{\mathrm{III}}$ & 0.000 & 0.00 & 0.033 & 0.64 \\
\hline $\mathrm{D}_{\mathrm{SLA}}$ & 0.101 & 1.19 & -0.005 & -0.12 \\
\hline $\mathrm{D}_{\mathrm{IV}}$ & $0.125^{\dagger}$ & 1.50 & $0.099 *$ & 1.75 \\
\hline $\mathrm{R}^{2}$ & \multicolumn{2}{|c|}{0.88} & \multicolumn{2}{|c|}{0.77} \\
\hline $\operatorname{Adj} R^{2}$ & \multicolumn{2}{|c|}{0.85} & \multicolumn{2}{|c|}{0.72} \\
\hline
\end{tabular}


Table V

Johansen's Multivariate Cointegration Test for $\Delta \mathbf{T F P}_{\mathbf{G}}$

\begin{tabular}{lcccccc}
\hline $\begin{array}{c}\text { Null } \\
\text { Hypothesis }\end{array}$ & $\begin{array}{c}\text { Eigen- } \\
\text { value }\end{array}$ & $\begin{array}{c}\text { Trace } \\
\text { Statistic }\end{array}$ & $\begin{array}{c}5 \text { Percent } \\
\text { Critical Value }\end{array}$ & $\begin{array}{c}\text { Max-Eigen } \\
\text { Statistic }\end{array}$ & $\begin{array}{c}5 \% \\
\text { Critical Value }\end{array}$ & $\begin{array}{c}\text { Hypothesized } \\
\text { No. of CE(s) }\end{array}$ \\
\hline $\mathrm{H}_{\mathrm{o}}: \mathrm{r}=0$ & 0.64 & $86.42^{*}$ & 69.82 & $46.45^{*}$ & 33.88 & None \\
$\mathrm{H}_{\mathrm{o}}: \mathrm{r} \leq 1$ & 0.26 & 39.97 & 47.86 & 14.08 & 27.58 & At most 1 \\
$\mathrm{H}_{\mathrm{o}}: \mathrm{r} \leq 2$ & 0.24 & 25.90 & 29.80 & 12.59 & 21.13 & At most 2 \\
$\mathrm{H}_{\mathrm{o}}: \mathrm{r} \leq 3$ & 0.20 & 13.30 & 15.49 & 10.29 & 14.26 & At most 3 \\
$\mathrm{H}_{\mathrm{o}}: \mathrm{r} \leq 4$ & 0.06 & 3.01 & 3.84 & 3.01 & 3.84 & At most 4 \\
\hline
\end{tabular}

*Trace and max-eigenvalue test indicate at most one cointegration equation at $5 \%$.

Variables included are diff TFPG, diff $\mathrm{K} / \mathrm{L}$, and diff $\mathrm{L}_{\mathrm{N}} / \mathrm{L}$, exchange rate, US housing starts $\mathrm{H}$.

Table VI

ECM for $\triangle$ TFP $_{\mathbf{G}}$

\begin{tabular}{|c|c|c|}
\hline Variables & Coefficient & t-values \\
\hline Error Correction Term ${ }^{a}$ & $-0.668 * * *$ & -4.39 \\
\hline Diff. $\Delta \mathrm{TFP}_{\mathrm{G}-1}$ & -0.106 & -0.69 \\
\hline Diff. $\Delta(\mathrm{K} / \mathrm{L})_{-1}$ & 0.667 & 0.14 \\
\hline Diff. $\Delta\left(\mathrm{L}_{N} / \mathrm{L}\right)_{-1}$ & $-1.783 *$ & -1.70 \\
\hline Constant & $-0.277^{\dagger}$ & -1.39 \\
\hline $\mathrm{E}$ & 0.188 & 1.25 \\
\hline $\mathrm{H}_{\mathrm{US}}$ & 0.0001 & 0.95 \\
\hline $\mathrm{D}_{\mathrm{II}}$ & $-0.084^{\dagger}$ & -1.32 \\
\hline $\mathrm{D}_{\text {III }}$ & $-0.182 * *$ & -2.27 \\
\hline $\mathrm{D}_{\mathrm{SLA}}$ & -0.041 & -0.57 \\
\hline $\mathrm{D}_{\mathrm{IV}}$ & -0.027 & -0.37 \\
\hline $\mathrm{R}^{2}$ & \multicolumn{2}{|c|}{0.45} \\
\hline $\operatorname{Adj} R^{2}$ & \multicolumn{2}{|c|}{0.30} \\
\hline
\end{tabular}


Table VII

Johansen's Multivariate Cointegration Test for Canadian Imports M

\begin{tabular}{lcccccc}
\hline $\begin{array}{c}\text { Null } \\
\text { Hypothesis }\end{array}$ & $\begin{array}{c}\text { Eigen- } \\
\text { value }\end{array}$ & $\begin{array}{c}\text { Trace } \\
\text { Statistic }\end{array}$ & $\begin{array}{c}\text { 5 Percent } \\
\text { Critical Value }\end{array}$ & $\begin{array}{c}\text { Max-Eigen } \\
\text { Statistic }\end{array}$ & $\begin{array}{c}\text { 5 Percent } \\
\text { Critical Value }\end{array}$ & $\begin{array}{c}\text { Hypothesized } \\
\text { No. of CE(s) }\end{array}$ \\
\hline $\mathrm{H}_{\mathrm{o}}: \mathrm{r}=0$ & 0.56 & $96.71^{*}$ & 69.82 & $37.43^{*}$ & 33.88 & None \\
$\mathrm{H}_{\mathrm{o}}: \mathrm{r} \leq 1$ & 0.45 & $59.28^{*}$ & 47.86 & $27.84^{*}$ & 27.58 & At most 1 \\
$\mathrm{H}_{\mathrm{o}}: \mathrm{r} \leq 2$ & 0.31 & $31.44^{*}$ & 29.80 & 16.96 & 21.13 & At most 2 \\
$\mathrm{H}_{\mathrm{o}}: \mathrm{r} \leq 3$ & 0.26 & 14.49 & 15.49 & 14.00 & 14.26 & At most 3 \\
$\mathrm{H}_{\mathrm{o}}: \mathrm{r} \leq 4$ & 0.01 & 0.39 & 3.84 & 0.39 & 3.84 & At most 4 \\
\hline
\end{tabular}

*Trace test indicates at most three cointegration equations, while max-eigenvalue tests indicate at most two cointegration equations at $5 \%$.

Variables in log form are: Canadian softwood lumber imports, exchange rate, US housing starts, Canadian softwood lumber price index, and US softwood lumber price index.

Table VIII

ECM for Canadian Imports M

\begin{tabular}{|c|c|c|}
\hline Variables & Coefficients & t-values \\
\hline Error Corr Term $1^{a}$ & -0.035 & -0.16 \\
\hline Error Corr Term $2^{b}$ & $0.412 *$ & 1.79 \\
\hline Diff. $\ln \mathrm{M}_{-1}$ & $-0.352^{\dagger}$ & -1.36 \\
\hline Diff. $\ln E_{-1}$ & -0.554 & -1.07 \\
\hline Diff. $\ln \mathrm{H}_{-1}$ & $0.701 * * *$ & 4.00 \\
\hline Diff. $\ln \mathrm{P}_{\mathrm{m}-1}$ & -0.070 & -0.22 \\
\hline Diff. $\ln \mathrm{P}_{\mathrm{d}-1}$ & -0.251 & -0.68 \\
\hline Constant & $0.095 * * *$ & 4.29 \\
\hline $\mathrm{D}_{\mathrm{II}}$ & $-0.117 *$ & -2.26 \\
\hline $\mathrm{D}_{\text {III }}$ & 0.049 & 0.65 \\
\hline $\mathrm{D}_{\text {SLA }}$ & $-0.077^{\dagger}$ & -1.56 \\
\hline $\mathrm{D}_{\mathrm{IV}}$ & $-0.097 *$ & -1.94 \\
\hline $\mathrm{R}^{2}$ & \multirow{2}{*}{\multicolumn{2}{|c|}{$\begin{array}{l}0.56 \\
0.42\end{array}$}} \\
\hline $\operatorname{Adj} R^{2}$ & & \\
\hline
\end{tabular}

${ }^{\mathrm{a}}$ Coint eq1 $=6.51+1.0 \ln \mathrm{M}_{-1}-0.75 \ln \mathrm{H}_{-1} * * *-1.07 \ln \mathrm{P}_{\mathrm{CN}-1} * * *-0.36 \ln \mathrm{P}_{\mathrm{US}-1}$

${ }^{\mathrm{b}}$ Coint eq $2=3.71+1.0 \ln \mathrm{E}_{-1}-0.44 \ln \mathrm{H}_{-1} * * *-0.90 \ln \mathrm{P}_{\mathrm{CN}-1} * * *+0.77 \ln \mathrm{P}_{\mathrm{US}-1} * *$.

$* * *, * *, *$, and ${ }^{\dagger}$ indicate significance at $1 \%, 5 \%, 10 \%$, and $20 \%$. 